\title{
COVID-19 MONITORING AND TRACKING SYSTEM USING INFORMATION TECHNOLOGIES AND ARTIFICIAL INTELLIGENCE
}

\section{SYSTEM MONITOROWANIA I ŚLEDZENIA COVID-19 Z WYKORZYSTANIEM TECHNOLOGII INFORMACYJNYCH I SZTUCZNEJ INTELIGENCJI}

\author{
Igor Vikhrov $^{1(\mathrm{~A}, \mathrm{~B}, \mathrm{C}, \mathrm{D}, \mathrm{E})}$, Sherzod Ashirbaev ${ }^{1(\mathrm{~F}, \mathrm{G})}$ \\ ${ }^{1}$ Innovation Center, Tashkent Pediatric Medical Institute, Tashkent, Uzbekistan
}

Authors' contribution

Wkład autorów:

A. Study design/planning

zaplanowanie badań

B. Data collection/entry

zebranie danych

C. Data analysis/statistics

dane - analiza i statystyki

D. Data interpretation

interpretacja danych

E. Preparation of manuscript przygotowanie artykułu

F. Literature analysis/search wyszukiwanie i analiza literatury

G. Funds collection

zebranie funduszy
Tables: 0

Figures: 1

References: 5

Submitted: 2021 Jul 15

Accepted: 2021 Aug 3

\section{Dear Editor,}

The appearance of COVID-19 almost coincided with the beginning of an active phase of the digitalization process in all areas, including public health. Moreover, COVID-19 unwittingly became an impulse that accelerated the introduction of digital technologies, as well as initiated new innovative solutions to combat both the virus and its devastating social and economic consequences. At the time of writing this letter to the Editor, COVID-19 is still actively spreading, having a negative impact on the global economy and health, despite the start of global vaccination. In this regard, the governments of all countries are developing new innovative approaches to prevention, treatment and rehabilitation of the virus.

Most of the countries faced with the coronavirus relied on the use of classical epidemiological measures to combat the viral infection, including WHO recommendations. Nevertheless, being in the middle of the second year of the global fight against COVID-19, it has become obvious that without the use of the full range of existing digital technologies, it is difficult to effectively counteract the pandemic.

In this regard, WHO has developed recommendations for the fight against COVID-19, which consist in the organization of affordable testing, isolation and care for patients, as well as contact tracking. These epidemiological measures are the most effective strategy for interrupting the transmission of the COVID-19, and the role of digital technologies, for example, when tracking contacts of sick people, is decisive. Simultaneously according to WHO, it is necessary to strictly consider the ethical aspects related to the confidentiality, accessibility, security and accountability of the data obtained.

The existing approaches to the implementation of digital solutions for tracking contacts with COVID-19 are currently conditionally divided into three groups (Figure 1). This division is based on the methodology of the approach to tracking contacts at the national level.

Countries such as Israel and South Korea represent a centralized approach to tracking contacts, however, with this approach, the most serious criticism is the protection of personal data [1,2]. In this regard, most countries that use the official contact tracking applications apply a decentralized approach, which implies

Keywords: contact tracking, artificial intelligence, COVID-19

Słowa kluczowe: śledzenie kontaktów, sztuczna inteligencja, COVID-19

Vikhrov I, Ashirbaev S. COVID-19 monitoring and tracking system using information technologies and artificial intelligence. Health Prob Civil. 2022; 16(1): 1-2. https://doi.org/10.5114/hpc.2021.108378

Address for correspondence / Adres korespondencyjny: Igor Vikhrov, Innovation Center, Tashkent Pediatric Medical Institute, Bagishamal str. 223, 100140 Tashkent, Uzbekistan, e-mail: ipvikhrov@gmail.com, phone: +998 712603658 ORCID: Igor Vikhrov https://orcid.org/0000-0002-4333-8533, Sherzod Ashirbaev https://orcid.org/0000-0003-2491-5312

Copyright: (C) John Paul II University of Applied Sciences in Biala Podlaska, Igor Vikhrov, Sherzod Ashirbaev. This is an Open Access journal, all articles are distributed under the terms of the Creative Commons Attribution-NonCommercial-ShareAlike 4.0 International (CC BY-NC-SA 4.0) License (http://creativecommons.org/ licenses/by-nc-sa/4.0/), allowing third parties to copy and redistribute the material in any medium or format and to remix, transform, and build upon the material, provided the original work is properly cited and states its license. 
a voluntary consent to contact tracking and personal data processing [3,4]. A combination of two approaches, the so-called hybrid approach is used, for example, by Germany [5].

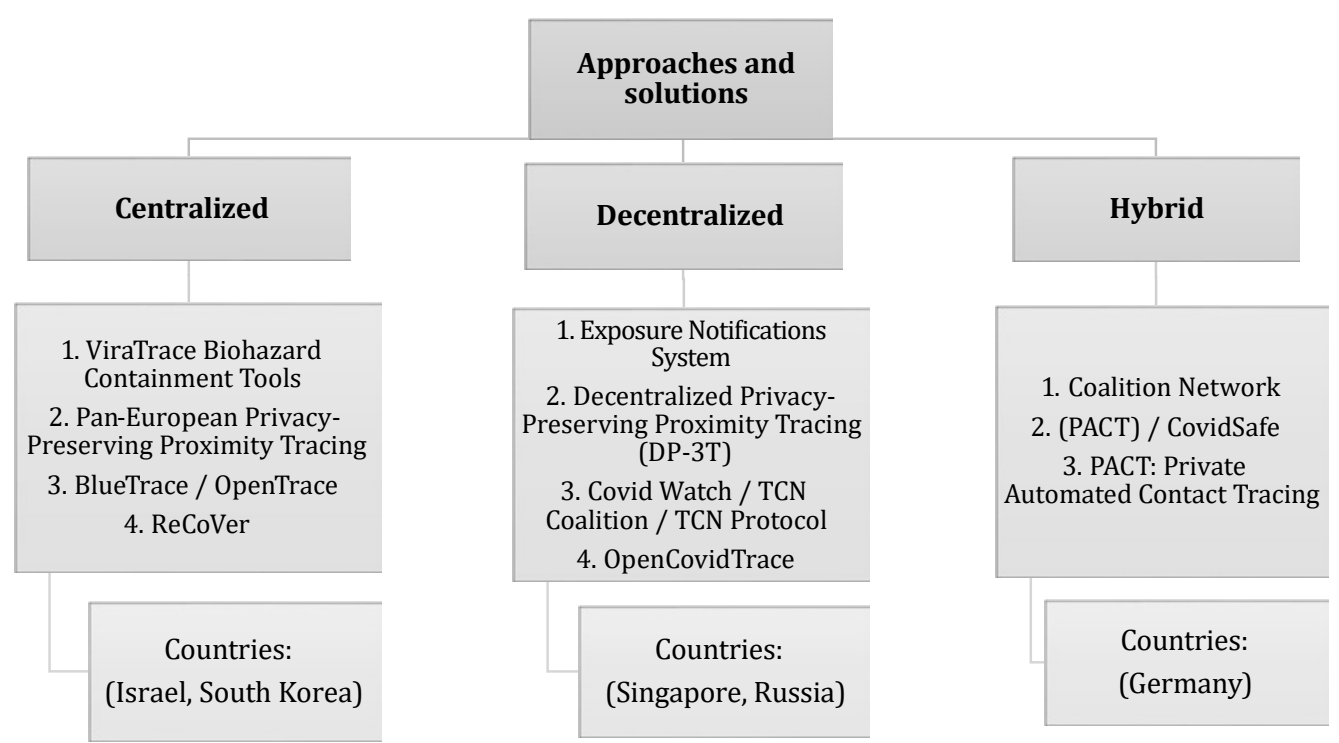

Figure 1. Approaches and solutions to the implementation of digital contact-tracing systems for COVID-19

The combination of digital technologies with artificial intelligence (AI) has made it possible to fight the pandemic more effectively and has led to the spread of mobile applications with AI for tracking contacts. At the same time, a number of ethical and regulatory issues remain a barrier to the dissemination of AI applications, in connection with which framework and ethical guidelines for the use of detailed technologies of responsible AI were proposed.

As for the population monitoring, there is still a gap in AI solutions that needs to be filled in terms of contact tracking and distancing methods. In contact tracking, the role of AI is not central, since the AI functions in contact-tracking applications are not deployed in most cases.

In Uzbekistan, digital solutions for tracking contacts with AI are still under development. Although numerous variants of COVID-19 mobile contact-tracking applications were proposed, they could not find their place in the official anti-epidemic measures of the Uzbek Government to combat the spread of infection. Nevertheless, the effective capabilities of such digital solutions for the epidemiological prevention of infection at the level of communities, cities and countries are beyond doubt.

\section{References:}

1. Amit M, Kimhi H, Bader T, Chen J, Glassberg E, Benov A. Mass-surveillance technologies to fight CoronaVirus spread: the case of Israel. Nat Med. 2020; 26: 1167-1169.

2. Park J, Cho S, Lee J, Lee I, Park W, Jeong S, et al. Development and utilization of a rapid and accurate epidemic investigation support system for COVID-19. Osong Public Health Res Perspect. 2020; 11(3): $118-127$. https://doi.org/10.24171/j.phrp.2020.11.3.06

3. Lai SHS, Tang CQY, Kurup A, Thevendran G. The experience of contact tracing in Singapore in the control of COVID-19: highlighting the use of digital technology. International Orthopaedics. 2021; 45: 65-69. https://doi.org/10.1007/s00264-020-04646-2

4. www.vesti.ru [Internet]. Moscow: All-Russia State Television and Radio Broadcasting Company; 2020 Nov 25. [The application of "Public Services. COVID tracker" in Russia] [cited 2021 May 16]. Available from: https://www.vesti.ru/hitech/article/2490022 (in Russian).

5. www.ito-app.org/ [Internet]. Track infections not people [cited 2021 May 16]. Available from: https://www.ito-app.org/ 